\title{
Exploration and Reflection on the Art Practice of Music Major in Independent Colleges
}

\author{
Chunyan Huang \\ Xiamen University Tan Kah Kee College \\ Xiamen, China 363105
}

\begin{abstract}
Art practice of music major in colleges is a driving force for deepening knowledge and an important way for cultivating students' innovative awareness and comprehensive ability, to make students of music apply their knowledge and skills in practice through various artistic activities inside and outside the classroom. The independent colleges focus more on the cultivation of applied talents so they have their characteristics in terms of personnel training objectives, curriculum setting, teaching methods and practical teaching. Based on the characteristics of independent colleges, this article explores and considers the construction of artistic practice in the music major.
\end{abstract}

Keywords—independent college; music major; art practice

\section{INTRODUCTION}

The music education system of independent colleges includes music theory knowledge, skill training and art practice. Art practice is complemented with theory study and skills training. From the point of view of learning for application, strengthening the artistic practice of music majors in independent colleges can help the class learning and promote the construction of knowledge systems. With the requirements of social development, the importance of art practice is getting higher and higher in the development of music major of independent colleges. This article analyzes the definition, meaning and construction of art practice, hoping to provide reference for music education in independent colleges.

\section{THE DEFINITION AND FORM OF ART PRACTICE OF MUSIC MAJOR IN INDEPENDENT COLLEGES}

\section{A. Definition of Art Practice}

The art practice is developed on the base of "teaching as the center," and it is an extension and supplement of curriculum learning in classroom. Students of music major should use the practice in classroom and at stage to show their knowledge and skills through understanding, analysis and performance. In the class of art practice, it is represented as learning, observation, and simulation of skills classes. Outside of class, it mainly is the demonstration of practical operation ability, to enhance practical innovation and social adaptability through concerts, professional competitions, performances and other forms.

\section{B. The Form of Art Practice}

1. The art practice on the campus is ubiquitous, which can be self-organized and planned, including the campus art variety activities organized by the students; simulated lectures, class (grade) concerts, and playing and singing practice party, graduation shows are developed under the guidance of teachers professional teacher teaching and concerts mobilize students to actively participate in art practice; schools organize college students' art festival, new and old students' New year evening party, alumni songs party and other cultural activities.

2. The art practice outside the school is rich and varied, including professional internships: acting as a student teacher in a primary or secondary schools, making practice in cultural organizations, etc.; participating in the performance of colleges and universities, military and other institutions; participating in the large-scale performances of local government and various organizations; participating and assisting in the programs arrangement, artistic training and counseling, etc. as well as various patterns of practices in youth palaces and training schools in the holiday.

\section{The SignificANCE of ART PRACTICE OF Music MaJor IN INDEPENDENT COLLEGES}

As a new type of undergraduate college, the Independen College advocates practical teaching and attaches importance to internship practice. And music majors pay more attention to the art practice and the value of practice: it enhances students personal professionalism and social competence, improves the quality of school personnel training and school's personnel training system.

\section{A. Art Practice Is An Indispensable Part of Art Education}

\section{1) Art Practice Supplements And Extends Classroom} Teaching

Art education includes two parts: art practice and classroom instruction. Students in music majors form systematic theoretical knowledge and professional foundations through classroom learning while apply the knowledge they have learned through artistic practice. Art practice is also an important means to test the level and quality of classroom teaching. On the one hand, teachers can find deficiencies in students' practice, which offers themselves opportunities to tap problems in classroom teaching, and thus actively adjust course content and knowledge system, strengthen course study 
and skills training in weak links. On the other hand, it helps students to master and absorb the theory and skills taught by teachers and apply them to practice. They perceive and discover problems in the process to correct and make up for their own deficiencies in classroom learning.

2) Art practice is the driving force for professional ability improvement

The artistic practice of music major is very professional. Art practice provides students with a good stage for presentation and performance. In turn, through the practice of art, students can not only apply theoretical knowledge to practice on the stage and combine excellent professional skills with rich experience in stage performance, but also they can understand their own professional capabilities and standards more clear. All these features are conducive to promoting the improvement of students' professional standards, the consolidation of professional knowledge, the upgrading of skills and the accumulation of practical experience, and meanwhile, they are helpful for teaching-learning to promote each other.

\section{3) Art practice can stimulate the enthusiasm of learning}

Artistic practice is closely related to the honor of an individual or a team. To a certain extent, it also gains recognition of the society for individual's professional level and ability, which will make students feel the charm of the music profession, thereby stimulating their interest in learning and enhancing their enthusiasm and initiative for learning.

Against the background of "widespread entrepreneurship and innovation", the demand for art talents in the society is getting higher and higher, and employment competition is also getting fiercer and fiercer. These will stimulate students to actively seize opportunities for practice and enhance their abilities and professional skills.

\section{4) Art practice promotes the integration of interdisciplinary knowledge}

Our society demand music talents have all skills of "blowing, pulling, playing, singing, dancing, weaving and guiding". At present, the curriculum and classroom teaching of music majors in Independent Colleges are limited, and it is difficult to achieve such goals. Yet, artistic practice can well make up for this deficiency. In art practice, there are various forms, and the content and style of works are also required to be rich and colorful. In response, music talents need to broaden the learning in other professional fields. Correspondingly, interdisciplinary links and integration will be strengthened and the field of knowledge learning will be expanded.

\section{5) Art practice is the motive force of teaching reform}

Independent Colleges shall directly face the multi-level and various kinds of talent market needs and the personal development demands of multiple choices and changes. Based on this understanding, the thinking of running a school for the talent market and seeking development through the market has been established. At the same time, the concept of building a talent training model of wide caliber, strong foundation, and outstanding capability has come into being. Through integrating into society, artistic practice will combine social needs with the training of school personnel to guide the direction of music majors, and then continue to promote professional curriculum construction and curriculum system adjustment and finally, teaching reform will be achieved successfully.

\section{B. Art Practice Is An Important Channel for Cultivating Innovative Talents}

1) Training students' comprehensive ability through artistic practice

Art practice provides students with enough choices of displaying their talents and empowering their abilities, enabling them to fully demonstrate their expertise and abilities. In the process, classmates learn from each other, understand their own deficiencies, learn from each other, and then, they complement one another perfectly to fully exert their own subjective initiative. On the basis of the ability to tap art talent, students have the conditions to continuously learn knowledge, improve their ability to adapt, practice and innovate. Finally, they will gain overall enrichment of their qualities.

2) Cultivating students' individualized development through art practice

The music major students of independent colleges have different growth experiences due to their growth in different regions and different family environments. After entering university, although they studied the same major, each individual's accomplishment, ability, life experience, and inner feelings are different. This has led to the differentiation of individuality. Art practice provides space for the development of students' personality. Students participate in various artistic practices in their own unique ways and pursue different goals. In correspondence, the original personalization gets even more obvious and individuality gets further development.

3) Cultivating students' good morality through artistic practice

Art practice enables students to contact the society, understand the society, and feel the current social economy and culture development as well as the society's needs and requirements for music in advance, thus making them establish a belief in the contribution to the development of the music industry and a sense of urgency and mission. At the same time, through artistic practice, it is possible to strengthen communication and contact among students and enhance team cohesion and cooperation spirit. These are all required for good morality.

4) Promoting students' socialization through artistic practice

Socialization is the process by which natural persons are transformed into social people. This is the stage that everyone must go through. Education is the main way of the socialization process. Learning promotes the socialization of students through instructing social norms and requirements to students in a planned manner. As a carrier of education, artistic practice also shoulders the important task of students' socialization. Through artistic practice, students can contact the society and understand the society in advance accompanied by increasing their social experience, which does favor to reserve the corresponding ability for the advancement of society to adapt to social claim. 
5) Making students more adaptable to the requirements of social talents through artistic practice

With the development of society, competition has become fiercer, and society has become more and more demanding for students of music majors: They not only need the professional knowledge of music, but also need cross-field knowledge; not only some certain skills are needed, but more comprehensive skills are needed. Classroom learning is not able to meet the needs and artistic practice is strongly required. In actual activities, it's necessary for students to continuously learn, comprehend, and exercise so that they can internalize their own capabilities and adapt to evolving social requirements.

\section{The Construction of Musical ARt Practice} MODE

Art practice is an important link in the education and teaching of music majors in Independent Colleges and occupies an important position in the school's talent cultivation system. It is a crucial platform for cultivating and training students. Meanwhile, it plays a vital role to display the results of school running. In view of the problems existing in the current artistic practice of music majors, the author thinks about the construction of artistic practice modes as follows.

\section{A. Deepen the Reform of the Art Practice Curriculum System}

\section{1) Improve the practical curriculum system}

The art practice curriculum system is different from the traditional theoretical classroom system and it is a combination of theory and practice, which determines that it has its own distinct characteristics. According to the training objectives of music professionals, students are required not only to have superb professional skills, but also to have excellent comprehensive qualities of excellent organization and coordination. In order to promote the perfect integration of art practice courses and practice, combined with the characteristics of artistic practice, the art practice curriculum also has the features of openness, flexibility, and more practicality, and more humanities factors have been added into, so that the foundation of students' good performance in artistic practice can be well laid. Inadequacies of students in artistic practice should also be communicated and shared in a timely manner so that problems can be resolved in time. Therefore, in the process of building an art practice curriculum system, the following points should be grasped: 1 . closely in line with the training objectives, and serve to guide the art practice; 2 . set dynamic, constantly-adjusted curricular goals, and solve problems found in the art practice in a timely manner; 3 . in the art practice curriculum, students should be guided to establish correct values, enhance overall humanistic qualities, and stimulate enthusiasm for participation.

\section{2) Realizing diversification of practical course content}

Art practice requires all aspects of the students' quality. Therefore, practice courses should focus on cultivating students' necessary abilities and qualities in all aspects. First, good social practice requires students to have superb performing abilities and professional skills. In the course of teaching, teachers should pay attention to the techniques that can be applied in specific art practice. Throughout the course teaching, the problems that may arise in practice and the teaching of artistic expression should be injected in the whole class to greatly enrich information volume of the class and boost students' application skills and interest in learning. Secondly, as we all know, music is a performing art, which makes viewers feel aesthetically pleasing through various forms such as singing and musical instruments. Artistic practice is a process in which students re-create what they have learned and it is not only the performance of the professional skills they have gained, but also a fusion of multi-faceted qualities, so teachers should focus on cultivating students with overall qualities, so that they can attain more knowledge reserve of art practice. Furthermore, the contents of the artistic practice curriculum should be more practical and focus on cultivating students' ability to solve practical problems. Therefore, teaching in practice is a very appropriate method. For example, teachers organize teaching during a certain orchestra event, allowing students to put themselves in specific situations, understand the familiar layout, sound effects, planning, and other aspects of the arrangement, which help students develop the ability of organization and coordination. Besides that, their professional skills and artistic performance can be played incisively. Teachers should play a guiding role in teaching by encouraging students to stimulate potential, carefully guiding the solution to solve emerging problems, and cultivating students' overall quality and enthusiasm for participation.

\section{B. Construction of Practical Ability Training Platform}

\section{1) Arrange practical activities in class reasonably}

In-class practice refers that students perform what they have learned in the form of practice in your class, which is an extended practice of the theory you have learned with diverse specific forms, including various assessments and reporting performances. Students experiencing and toughening their professional skills in the practice of performance and at the same time, they can check the coincidence between theoretical knowledge and practice. Through continuous practice activities, they can check and improve their artistic expression of professional skills gradually. At the same time, the school needs to provide enough venues and funds to ensure the implementation of practical activities and set up different venues to meet different performance needs.

2) Create a good atmosphere of art practice in school

On-campus art practice refers to various art practice activities held in the school, including common variety of art evenings and it provides an excellent stage for examining student performances. In general, students are less relaxed when they are practicing under the class and have fewer accidents. However, once they are on the stage and face the audience, due to lack of skills and poor psychological quality, they are prone to get trapped into "stage syndrome", such as facial stiffness and limb disharmony, which more or less affect performance. Therefore, students should seize the opportunity of practice within the school and strive to improve their performance skills and stage performance, so that they can temper their own stage style.

Practical activities in schools can be organized by individuals and the school party. Students are allowed to meticulously organize solo recitals; they can also organize art 
appreciation activities in classes and carry out various forms of sharing and exchange meetings; they can organize reporting performance taking one grade as a unit. The school can take all kinds of festivals as opportunities to organize various celebration activities; it can also integrate school resources, establish partnerships with other schools to jointly organize various types of theatrical performances; introducing highquality art resources and invite artists or groups to perform in schools is another choice.

3) Go deep into the society to carry out the practice of art

Social art practice activities refer to various types of performances and competitions that are conducted outside the school. As a broader stage for the audience, social art practice activities also provide students with a more powerful touchstone for testing the stage effects. The practice of art in society not only meets the spiritual needs of ordinary people and satisfies their aesthetic needs, but it can make students deeply understand the social outlook and draw inspiration of art creation, making from it, making art rooted in life and counteracting life. While stepping into social life deeply, students should incorporate national and traditional factors into their works to inherit the fine culture of the Chinese nation. From the school level, they should take the initiative to visit various types of enterprises to select suitable platforms for students to implement art practice, establish stable cooperation relationships, and provide students with an excellent platform for off-campus art practice. Among them, all kinds of cultural groups are friendly partners who carry out long-term close cooperation, and schools should focus on building platforms for art practice at all levels.

Students should also take the initiative to participate in various types of competition organized by the society, find their own shortcomings in the game, and also cooperate with excellent opponents. The competition under pressure is not only a test for students' professional skills and artistic expression, but also an examination of psychological quality and other comprehensive qualities. By participating in various competitions, students can gain certain improvements at different stages and then, gradually increase their artistic level.

\section{Perfecting the Management and Assessment Mechanism of Art Practice}

In order to ensure that artistic practice achieves good results, schools should set detailed art practice theories and practice goals, which are adjusted proportions by the teacher between theory and practice according to students' different levels. In the setting of training objectives, professional skills, artistic expression, and innovation ability should be listed as important indicators of assessment. According objectives, teachers should adopt strict assessment methods to ensure that students meet the requirements of training objectives in both theory and practice. In the assessment of practice, there are different methods to be adopted, For example, students can evaluate themselves or evaluate each other. What's more, they can submit reports to teachers. In addition, some other suitable forms also can be adopted. Teachers should come up with new training objectives in accordance with the effectiveness of students' art practice to strengthen the guiding role of artistic practice assessment.

\section{CONCLUSION}

The artistic practice of music major in Independent College has a great role in promoting students' professional development and overall quality.

Therefore, schools should increase the exploration and thinking of the teaching mode of art practice. In practice, it is sensible for the school to constantly optimize the forward direction of art practice, enhance the participation of students, and at the same time pay attention to the improvement of the quality of art practice, so that, they can cultivate high-quality talents for the society.

\section{REFERENCES}

[1] Bo Wang. Research on the Teaching Model of Artistic Practice in Music Major of Local Colleges [J].Journal of Jiangxi Institute of Education,2013(06).

[2] Yufeng Zhang. Research on Current Situation of Art Practice Teaching of Musicology in Shandong Colleges and Universities [D].Shandong University,2015.5.

[3] Yanchun Tang. The Construction of the Course System of Artistic Practice in Normal University Musicology[J]. Education and Teaching Forum,2014(25). 